\title{
Identity Negotiation in Chinese University English Classroom
}

\author{
Nan Zhou ${ }^{1}$ \\ ${ }^{1}$ Graduate School of Education, University of California Berkeley, California, USA \\ Correspondence: Nan Zhou, 1040 Jackson St, Albany, CA USA. Tel: 1-510-604-7113. E-mail: \\ nanzhou@berkeley.edu
}

Received: March 15, 2018

Accepted: March 30, 2018 Online Published: January 30, 2020

doi:10.5539/hes.v10n2p1

URL: https://doi.org/10.5539/hes.v10n2p1

\begin{abstract}
Through a theoretical framework that builds on the Community of Practice construct and the concepts of identity negotiation, imagined identity and investment, this case study examines how one English-as-a-foreign-language student negotiated the identity as an English learner in the Chinese university classroom setting. Then the extent that the student's oral communication behaviors in the English classroom community were influenced by the negotiated identity is presented. The analysis shows that a student may have multiple identities in the educational setting. By constantly shifting identities in the English learning process, the focal student struggled with the English learner identity perceived by herself and that identified by her English teacher. As a result, the student's investment in English class oral tasks and communication behaviors in EFL classroom may change with the shift of identities. Suggestions are made for EFL teachers to help students construct desirable identities in order to improve their involvement in English class oral communication activities.
\end{abstract}

Keywords: classroom oral participation, identity, community of practice, legitimacy, investment, second language

\section{Introduction}

In China, where students have few opportunities to use English outside the classroom, class learning is crucial to English acquisition. It is often emphasized that language development and learning is enhanced when the level of interaction rises (Kang, 2005). Hence many scholars focus on learners' level of classroom participation, and the factors that contribute to students' passive class oral behaviors (Cheng, 2000; Liu, 2005; Peng, 2007; Peng \& Woodrow, 2010).

Research indicates that students' learning behaviors are not stable and their academic practices might change across educational contexts (Cao \& Philp, 2006; Peng, 2007; Peng \& Woodrow, 2010; Wen \& Clément, 2003). In 2003, Wen and Clément explored Chinese students' unwillingness to communicate in English classrooms from cultural and philosophical perspectives. The researchers found that Chinese students' Willingness to Communicate (WTC) in English classroom settings was affected by group cohesiveness, teacher support, affiliation, task-orientation, risk-taking, tolerance of ambiguity, inhibited monitor and positive expectation of evaluation. In Peng's (2007) qualitative study among 118 Chinese university students, she identified eight factors affecting students' WTC: communicative competence; language anxiety; risk-taking; learners' beliefs; classroom climate; group cohesiveness; teacher support; and classroom organization. In 2010 Peng and Woodrow reported a quantitative study among 579 students from eight universities in Eastern China. They investigated Chinese tertiary students' willingness to use English in classroom communication, from an ecological perspective in relation to classroom dynamics. It was found that students' willingness to communicate in English in classroom setting was influenced both directly and indirectly by the joint effect of communication confidence in English, learner beliefs, classroom environment and motivation to learn English. Communication confidence in English exerts a strong and direct influence on students' willingness to communicate in English classroom. Even though English-as-a-foreign-language (EFL) learners' passive classroom oral behaviors have received extensive concern from scholars, few studies put their attention on the situated identities experienced by students in the learning process when investigating their oral communication in the classroom setting.

The strongest significance of the study lies in its focus on EFL students' identity negotiation in the English learning process. Scholars with a sociocultural perspective understand identity as fluid and multiple. Identity is produced as a lived experience of participation and non-participation in specific communities (Wenger, 1998). 
Students' investment in learning is actually an investment in their own identity, which is constantly changing across time and space (Norton, 2013). "It's only by acknowledging the complexity of identity that we can gain insight into the myriad challenges and possibilities of language learning... (Norton, 2013, p. 191)" Therefore, exploring how learners construct and negotiate their identities in the learning process may contribute to understanding their classroom behaviors.

The study is also distinctive by viewing English classroom as a community of practice (CoP), with teacher and students as members of this community. It helps to understand students' learning practices in English classroom by examining their (non)participation in the activities of the English classroom community and interaction with other members of this community, and how they are (self-)positioned in the classroom community. This suggests a new perspective to understand students' classroom behaviors.

\section{Theoretical Framework}

The theoretical framework of this study builds on the construct of Community of Practice (Lave \& Wenger, 1991; Wenger, 1998). Such concepts, which frequently appear in the CoP construct as identity negotiation (Chen, 2010; Norton, 2000; Pomerantz, 2001; Swann, 1987; Wenger, 1998), investment (Kubota, 2011; Norton, 1995; 2000) and imagined community/ identity (Kanno \& Norton, 2003; Norton, 2001; Pavlenko \& Norton, 2007; Wenger, 1998) are used within the CoP framework to gain an understanding of how Chinese university students' oral communication behaviors in EFL classroom are relevant to their ever-changing identities as English learners.

\subsection{Community of Practice}

The term "Community of Practice" was introduced by Lave and Wenger in Situated Learning: Legitimate Peripheral Participation (1991). Challenging traditional thinking about learning, they explore the notion of human understanding and learning as situated in certain forms of social participation. Wenger, McDermott and Snyder (2002) define community of practice as follows:

"A unique combination of three fundamental elements: a domain of knowledge, which defines a set of issues; a community of people who care about this domain; and the shared practices that they are developing to be effective in the domain" (p. 26-27).

This study adopts community of practice as the primary theoretical framework because it is "a powerful analytical tool in unveiling the complexity of contexts", and "critically analysing its components and characteristics appears to be beneficial in ... understanding identity negotiation within a particular context" (Chen, 2010, p. 177). In the theorization of CoP, the concept of legitimate peripheral participation is particularly useful for the present study. According to Lave and Wenger (1991, p. 19), in a community of practice "learning would be likely to take place whenever people interact under conditions of legitimate peripheral participation". Legitimate peripheral participants in a $\mathrm{CoP}$ tend to handle themselves more competently and gain more improvement and advancement than those who are not (Wenger, 1998). This concept broadens the traditional concept of learning from the teacher-student relationship to the processes of changing participation and identity transformation in a CoP (Wenger, 1998). This suggests that legitimacy and peripherality, the two necessary conditions of participation in a CoP, are of great importance in understanding students' engagement in English classroom oral activities. Due to the limited scope of this article, this study only examines the interrelationship between students' legitimacy for participation and their EFL class oral performances, leaving the concept of "peripheral" untouched.

\subsection{Identity Negotiation}

Norton (2000) uses identity to reference how an individual understands his relationship to the world, how that relationship is constructed with the change of time and space, and how he understands possibilities for the future. Pomerantz (2001, p. 57) defines identity as the way in which people present a public sense of who they are and what they are doing at specific interactional moments. Drawing on the definitions of "identity" put forward by Norton (2000) and Pomerantz (2001), and based on Ting-Toomey's (1999) argument that one's identity can be approached from social and personal levels, "identity", in the present study, is defined as:

An individual's sense of who he is and of the position he holds in interaction with others, by integrating past, present experiences and expectations for the future in a specific EFL educational CoP.

Swann (1987) introduces the concept of identity negotiation. One's identity is a negotiating experience. We gradually acquire views of ourselves through communication and interaction with others, and it is also through communication and interaction that others acquire particular ways of thinking about us (Ting-Toomey, 1999). In EFL educational setting, students come to class with a sense of identity. When participating in class activities and interacting with teachers and peers, students are not only exchanging information in the English language, they 
are also "constantly organizing and reorganizing a sense of who they are and how they relate to the social world" (Norton, 2000, p. 166). They keep identifying their own positions and negotiating their identities in learning (Wenger, 1998). Their language learning, and their use or non-use of language, reflect and create their identities. Both the positive and negative consequences of identity negotiation can in turn affect the quality of interpersonal interactions and learners' involvement in communication (Lewis, 1997). It's hard to attain educational success without an attention to students' identity (Norton, 2013). Examining students' identity negotiation during their English learning process may cast light on the study of their English classroom communication and interaction.

\subsection{Investment}

Norton (2000) sees language learners as "individuals with complex social histories and multiple desires" (p. 11), rather than as "unitary, fixed, and ahistorical individuals" (p. 10). Inspired by Bourdieu's (1977) economic metaphors, Norton uses the term "investment", different from its traditional economic sense, to signal the "socially and historically constructed relationship of learners to the target language, and their often ambivalent desire to learn and practice it" (2000, p. 10).

Learning a language is a form of investment (Kubota, 2011). When language learners invest in a certain language, they expect to get a good return (Norton, 1995). In EFL classes, students draw on their past and present experience and their visions for the future, to construct and negotiate their identities as English learners and members of the English classroom community. This determines how much they invest in English learning and oral participation in class. The view that students' investment in the target language and class oral communication is also an investment in their learner identity (Norton, 2013) is employed in this study to understand the relevance between students' changes of English classroom oral behaviors and their shifted identities.

\subsection{Imagined Community/ Identity}

The term "imagined community" was first coined by Benedict Anderson (1991) to refer to communities that only exist in people's imagination. Norton (2001) adapts this term in L2 learning research and asserts that language learners' imagined identities in the L2 community exert great influence on their present language learning practices. Imagined community has become a prominent topic in L2 educational research (Kanno \& Norton, 2003; Pavlenko \& Norton, 2007). Wenger (1998) argues that "imagination" should be integrated to education. Students must have the scope to explore who they are, who they are not and who they could be. In the educational context, what students expect and imagine about the future can strongly influence their ongoing activities (Norton, 2000). When a learner learns in class, he not only invests in the classroom community, he also invests in the community that he expects to enter and the identities that he expects to have. Normally this future community/ identity is much more significant.

This theoretical framework offers an analytic tool for a dynamic exploration of the focal student's specific instances of class oral participation, her intentions underlying the specific ways of participation, and her choices of participation or non-participation. Perceiving the student evolution within this framework helps to understand her experience in the learning process (Norton, 2013). It also enables insight into how the student negotiated her identities as English learner and the extent that her frequency of class oral participation is affected by the shifted identities. These matters are central to the research questions of the present study.

\section{Research Methods}

This study is part of a large-scale $\mathrm{PhD}$ research investigating factors influencing Chinese university students' participation in English classroom oral tasks. This article explores students' identity negotiation in the English learning process and how the changed identities impact their oral performances in English classes by focusing on the situated identities of one student as an EFL learner. The research questions were (a) how did the EFL student negotiate identities in the English learning process? (b) how did the student's shifted identity impact her participation in English class oral tasks?

\subsection{Settings and Participants}

The primary field site was a comprehensive university located in northeastern part of Mainland China. Students have access to adequate English language learning materials, including English language newspapers, books and films. Students are encouraged to take part in a variety of English language related activities, including the English Cultural and Arts Festival, the English Short Play Contest, the English Debate Contest, and the English Speech Contest. As a large majority of universities in Mainland China, courses in English language are compulsory for all first- and second-year non-English major undergraduates. From the third year, the focus of English learning turns to English in a specific field, such as educational English, engineering English, and 
chemical English.

The focal student of this research was 19-year-old Yan $^{1}$, majoring in Chinese Education. She was purposely selected because of her significant changes of frequencies of English class oral participation in the first four observed English classes. Yan was born and grew up in a small city in Northeastern China. Her native language is Chinese. Her mother works in a middle school and her father is a businessman. At the beginning of the fieldwork, Yan had just completed the first semester of her undergraduate study and was about to start the second semester. Each week Yan took four English classes, with 45 minutes each. She participated in English Speech Contest held by her department in December 2009, and got the second place.

Mrs. Li was in her early 30s and a certified senior lecturer with 10-year EFL tertiary teaching experience at the time of research. Each week she taught three classes, with thirty to thirty-five students in each class. Mrs. Li was open-minded with an extroverted personality. She was a friend of her students, always joking with them, so her English class was often filled with laughter. Mrs. Li was aware of the importance of communication between teacher and students. She asked students to hand in English journals voluntarily at any time, on anything they wanted to share with her. After reading students' journals, Mrs. Li wrote her reflections on them in communication with the students. The diaries could cover any aspect of students' lives, such as family background, the difficulties students were confronted with in university study, and the achievements they attained.

In Mrs. Li's focal English class, there were 30 students, all from the college of humanities, with 14 majoring in Chinese Education and 16 in Journalism. All these 30 students know each other and are closely related. In this class 5 were male and 25 female; 18 from cities and 12 from the countryside. The ages ranged from 18 to 21 .

\subsection{Method and Data Analysis}

The research took place over 15 weeks, from February to June 2010. A triangulation of methods was used: semi-structured interviews, observations and stimulated recalls to "seek the convergence and corroboration of findings from different methods that examine the same phenomenon" (Powell et al., 2008, p. 294). Grounded theory was used to code the data qualitatively. Theories were developed after close analysis of the data. NVivo 9 (QSR International Pty Ltd, 2008), commonly used software in qualitative data analysis (Leech \& Onwuegbuzie, 2011), was used in classifying the data according to the codes. The researcher entered the focal class with the consent of every participant, who was aware of the purpose, process and possible influence of the research. The means of researcher-as-a-complete-observer (Herman, 2005, cited in Wilensky, 2011), in which the researcher enters the setting solely as an observer, known to be so, and does not interact with the subjects at all, was adopted.

English classes were delivered twice a week. Each time covered two periods, totally 90 minutes, with a 10-minute break in the middle. In total, $15 \mathrm{EFL}$ class periods were observed, with 45 minutes for each class period. Notes were taken during class observation and all observed classes were videotaped. In the first four weeks, the performances of all the students in the focal class were closely observed. The focus of the notes and video reviews was on examples of teachers' practices that encouraged or hindered students' oral participation in classroom activities, and on students' reactions to the particular teaching practices used. Then one student (named Yan) who experienced significant changes in her class oral participation during this period was selected.

Semi-structured interviews were conducted for Yan and Mrs. Li. Yan was interviewed twice, one in the fourth week immediately after she was selected and the other one at the end of the fieldwork. Each lasted approximately one hour and a half. The interview questions covered Yan's experiences in English learning and perceptions of factors affecting the extent of her participation in oral tasks. In order to ensure the accuracy of student recall, the researcher provided information about the condition under which class oral tasks were provided, or reviewed the video together with Yan.

Mrs. Li was formally interviewed once at the last stage of the fieldwork, lasting one hour. The focus was on her assessment of Yan's achievement in English learning and class oral participation, factors identified as influencing Yan's participation in English class oral tasks, and her perceptions of changes in Yan's class oral behaviors. In the interview the researcher integrated the class observations and the interviews with Yan. In the semester in which this fieldwork was conducted, the researcher also discussed with Mrs. Li informally about Yan's performances in English learning and English class once a week.

The researcher also talked informally with Yan's classmates in English class during the class breaks to gain their

\footnotetext{
${ }^{1}$ As is common in educational research, names of the participants in this study are pseudonyms.
} 
perception of Yan's learning behaviors and Mrs. Li's teaching practices.

The researcher posed questions to interviewees in an open-ended fashion to elicit their reflection on the identification of identities and class oral participation. All the interviews were conducted in Chinese. Member checking was done during interview process to increase the credibility of the study (Yanow \& Schwartz-Shea, 2006). When the researcher believed that the interviewees' statement might contribute to the study, she restated the information and then questioned them to determine accuracy. Field notes and audio tapes were used to record the interviews.

All the audiotaped interviews were transcribed. Then the classroom videotapes were reviewed so as to identify and analyze (a) the focal student's behaviors in English classroom and her interaction with the teacher and peers; (b) her participation in class oral tasks; and (c) detailed examples of the teacher's classroom practices that tended to encourage or hinder the focal student's oral participation.

The last step identified examples of identity negotiation experienced by the focal student in the course of the fieldwork, which tended to impact her English class oral performances. Then how the focal student's participation in English classroom oral tasks was influenced by the negotiated identities was analyzed.

\section{Findings}

Based on the data collected from the observed classes and interviews with the focal student Yan and her English teacher Mrs. Li, this section first discusses how Yan struggled with the identity perceived by herself and that identified by Mrs. Li. In this process she constantly shifted her identity as an English learner. Then the extent that Yan's oral communication behaviors in the English classroom community were influenced by the negotiated identity is presented.

In the university campus, Yan had multiple identities. She was extroverted in personality. As soon as entering university, Yan successfully competed for a position in the Student Union. Over the one semester of university study she actively participated in extra-curricular activities organized by University or Department, such as the Chinese Speech Contest and various volunteer works. She was well-known by the peers. In this respect, Yan's identity is a student actively participating in various kinds of extra-curriculum activities with high reputation among peers, which was confirmed by one of Yan's classmates in a casual talk with him during the break between two class periods (Wang, March $22^{\text {nd }}, 2010$ ).

In National College Entrance English Examination (NCEEE), Yan received a high score of 138 (the full score is 150). In the previous semester's final English examination she received 92 (the full score is 100), the highest score in the class. She was the Study Secretary of her own class (not the English class), a position in charge of the issues relevant to study. Usually students good at academic learning took this position. In the academic respect, Yan's identity is a student with high performances in English examinations. It is consistent with Yan's self-identity as an English learner. In the first interview with Yan, she stated "English had always been the strong point among subjects."

When discussing her own position in the English class community, Yan was not as confident as stated above. "I am merely an ordinary student." It coincided with what identified by Mrs. Li.

It is observed that Yan was active in oral participation in the first couple of English classes. Then she became more and more inactive. In the whole semester, Yan volunteered to participate in class oral activities 16 times, 13 in the first four classes. In the semester prior to the fieldwork, Yan communicated with Mrs. Li frequently by means of diary. However, according to Mrs. $\mathrm{Li}$, in addition to the one Yan handed in in the very beginning of the semester, she did not handed in a single piece of diary any more, which was also mentioned by Yan in interview.

In the following parts, this article will discuss how Yan constructed and negotiated her identities as English learner in the course of English classroom learning and how she changed her class oral communication behaviors with the shifts of identities.

In order to understand how Yan identified herself as an English learner in terms of the four language skills, i.e. listening, speaking, reading and writing, in the first interview she was asked to answer the following two questions:

Question 1: Which of the four English skills do you think are important for English learners?

Question 2: Which of the four English skills are important for you in the present stage?

Yan was allowed to choose more than one skill if she believed they were equally important. She stated:

"Speaking competence was the most important for English learners... Because the main function of a language is 
to communicate."

The above quote shows that Yan believed that speaking competence was the most important skill for English learners. When answering the second question about which of the four skills "are important for you in the present stage," there was variation. She regarded improving reading skills was her major concern, because:

"It (reading skill) accounts for the largest part in exams."

Then she added:

"Speaking skill is also useful. But I do not think it is important for me. I have nowhere to use it except in class."

The above quotations show that Yan tended to identify herself as a test-taker, rather than an English learner who needed to improve comprehensive English proficiency. Apparently, Yan did not regard one fluent at English oral communication as one of her imagined identities.

As for the identities that Yan longed for, she stated:

"I have always required myself to be outstanding among peers. In addition, I hope I can attract attention and attain recognition from people around."

The above excerpt shows that Yan's imagined identity in the English learning community basically composes two parts: being outstanding among peers and gain recognition from others. However, data obtained from class observation shows that Yan's imagined identity is not achieved in the English classroom community. In light of the CoP framework and the concepts of identity negotiation, investment and imagined community/ identity, this part will go on to discuss how Yan's imagined identity conflicted with her self-identity constructed in the process of participating in class activities and how she conformed to the identity she perceived to be identified by Mrs. Li. The discussion will focus on three themes, which have been observed to impact Yan's changes of identity and classroom oral behaviors: (a) lack of legitimacy for participation; (b) self-identity as an unvalued student in English class; and (c) disillusionment of imagined identity.

(a) Lack of Legitimacy for Participation

It is observed that Mrs. Li showed obvious preference for several students in class. She always cited these students as examples and designated them to answer questions when she believed high English proficiency was required. Chen was one of them. On February $22^{\text {nd }}$, when discussing with the students about how to balance the time they spent on academic learning and extra-curricular activities, Mrs. Li said:

"Chen, you are the Study Secretary of the class. Could you explain to us what you do to guarantee enough studying hours?"

On April $5^{\text {th }}$, when talking with the class about the English Speech Contest held two days prior, Mrs. Li turned to Chen and asked:

"Chen, did you go to the contest? Did you listen to the speech of the guy who got the first place in the end? What do you think of his performances?"

Similar examples occurred with several other students. Questioned about these practices in interview, Mrs. Li stated:

"I did not regard it as a problem. It is normal for the teachers to like the students who are active in class and are willing to cooperate with her. After so many years of schooling, the students have been used to that."

Nevertheless, Yan saw it differently. She mentioned Mrs. Li's special attention to Chen in interview and showed her disappointment:

"Mrs. Li likes Chen very much. She must not know there are two Study Secretaries in our class. One is Chen. I am the other one. She did not notice my English final examination score in the last semester is much higher than hers (Chen's)."

Mrs. Li's special attention to a small number of students made Yan feel that "the class is theirs" and identify herself as a student who was "not legitimate to participate". Compared to her peers, especially those preferred by Mrs. Li, Yan lacked access to the resources of the English classroom community. Then in order to bid for the desirable identity she had been longing for (her imagined identity) as excellent and outstanding among the peers, Yan put more efforts to participation in English class oral tasks. Gradually Yan realized that her excellence in English did not attract Mrs Li's attention, which will be further discussed in the next part.

(b) Self-identity as an Unvalued Student in English Class

As stated above, in the semester previous to the study, Yan was an active oral participant in English and 
frequently handed in diaries to Mrs. Li that discussed local events. However, in the semester in which the research was conducted, she only handed in one piece of diary and seemed less interested in oral participation. When asked why in the second interview, Yan became upset. She told the researcher that she was an active participant in English class until the beginning of the current semester when she realized that her excellence in English was not valued by Mrs. Li. Based on close examination of Yan's class performances and her own statement, three things happened at the beginning of the semester seemed to cause her construct of self-identities as a student not valued in English class, which impacted her English class oral participation.

In the first class of this semester (February $22^{\text {nd }}$ ), Mrs. Li asked in class who got the score higher than 90 in last semester's English final exam. Yan raised her hand proudly because she got 92, the highest score in the whole class. Two days later (February $24^{\text {th }}$ ), Mrs. Li asked the same question again. When she asked it the third time (March $3^{\text {rd }}$ ) in two weeks, Yan realized "Mrs. Li did not remember I got the first place at all." and that "my excellent performances in the examination has not attracted Mrs. Li's attention".

Later, another experience made Yan aware that in the eyes of Mrs. Li she was not as important as she expected. On March $15^{\text {th }}$, before teaching the text entitled Marriage across the Nations, Mrs. Li asked the class to discuss on the topics "What makes a happy marriage?" and "Will you accept marriage across nations?" The students were admitted 5 minutes to prepare and then volunteers were asked to present their own views to the whole class. The following is the excerpt from class observation.

(Five minutes was up.)

Mrs. Li: Who wants to share views about marriage across nations?

(Yan raised her hand.)

Mrs: (She looked at Yan for a few seconds.) Jiang, please. (Jiang is another girl in the same class.)

(Yan put down her hand. Mrs. Li was apparently a little surprised when Jiang stood up from another corner of the classroom.)

Jiang: ...

Mrs. Li: Very good. ..(She commented on Jiang's views.) Anybody else?

(Yan looked around, and then raised her hand again.)

Mrs. Li: (looked at Yan) You, please.

In interview Yan reviewed this excerpt and stated "I knew she (Mrs. Li) mixed me up with Jiang." Then Yan realized that she was merely one of the average students in class. She was not valued by the teacher and even was not remembered by name:

"Since Mrs. Li does not pay attention to me, it did not matter whether I am active or not."

Yan was self-identified as a student who was not valued by the teacher. It to some extent led to her decreased interest in oral participation. The things happened next made her totally lose enthusiasm for oral participation. For several times, after Mrs. Li proposed a question, Yan put up her hand. After noticing Yan's raised hand, Mrs. Li kept asking the class whether there was somebody else who wanted to answer the question. Mrs. Li explained that her purpose was to encourage more students to participate in oral tasks, which was apparently misunderstood by Yan:

"It seemed the task was not for me."

The above quotation was another instance of Yan's class oral participation being related to her self-identities as students lacking legitimacy for participation. Yan cited it as one of the reasons for her own gradual withdrawal into oral inactivity. It is in line with the literature that legitimacy is one of the factors which enable members of a CoP gain access to that CoP (Wenger, 1998).

As stated above, one aspect of Yan's imagined identity was a student outstanding among peers. It is easy to be achieved due to her strong English language foundation. According to Yan, "I can get rather high score in English examinations without working hard on it." However, with the construction of self-identity as an unvalued member in the English classroom, Yan realized her imagined identity of gaining recognition and attention from teacher and classmates could not be achieved in the English classroom community. As a result, she gradually reduced her investment in class oral participation. Her enthusiasm for English learning and oral participation decreased. Yan even reduced her investment in English learning. She did not hand in diaries to Mrs. $\mathrm{Li}$ and sometimes did not finish after-class assignments. These reinforced Mrs. Li's identification of Yan as an inactive English learner. 


\section{(c) Disillusionment of Imagined Identity}

Throughout the interview (both the first and the second), Yan mentioned her experiences in high school repeatedly. The excitement of her English learning experience in high school formed a sharp contrast with the disappointment of her English study at tertiary level. From primary school to senior high school, Yan's examination results in all the subjects ranked in the first five places in class. Valued by teachers and recognized by classmates, she was actively involved inside and outside class, including oral tasks in English.

Yan revealed her pride in her English learning experience in high school:

"I am free to express myself in class."

After entering university, especially in the current semester, Yan found her identity in class was different. As discussed above, Yan's objectives for English class oral participation were to show her excellence. Her imagined identity in the university English class community was an outstanding student who attained the recognition from teachers and classmates. In the beginning of university learning, Yan tried to enact the imagined identity by making active investment in all kinds of activities which helped her to attract others' attention, including English class oral tasks. With the course went on, due to the incidents cited above, she realized that her investment in English class oral participation seemed not helpful of gaining what she had expected to attain as a return, and that her imagined identity as an outstanding student well-known by peers could not be achieved by means of investing in English learning and class oral participation as in high school, she became disillusioned:

"Li must not know I am good at English. In her view, I am only an average student who sometimes did not complete assignment on time and is not active in class activities."

Even though Yan's imagined identity as a valued and outstanding student was disillusioned in English class, Yan revealed in the second interview that she still tried to enact the desired identity by actively participating in the classroom tasks of other courses and extra-curriculum activities in the campus. It was confirmed by one student from the focal class (Zhan, June $2^{\text {nd }}$ ):

"Yan was famous in the campus. She was the prize winner of many contests. She was also the Vice-chairman of the Volunteer Society of the Department."

In the second interview, Yan explained:

"Because I feel I am supported in my self-worth (when participating in the above mentioned activities)."

Even though Yan's investment in participating in English class oral tasks decreased, she kept investing in the activities which she believed helpful to achieve her imagined identity.

In sum, the discussion of Yan's identities as English learner in the EFL classroom community of practice demonstrated that students' identities are in a constant state of negotiation in the learning process and that the ever-shifting identities impact their involvement in English class oral tasks. In the beginning of entering university English classroom community, excellent examination results constructed Yan's self-identity as an advanced English learner. With the course moved on, under the influence of the practices of other members of the community (i.e. teacher and classmates), Yan's identities shifted. The analysis of Yan's investment in English learning and her imagined identities shed light on the reasons for her identity negotiation and changes of class oral performances. When Yan realized her imagined identity as an outstanding member of a community could not be enacted, she conformed to the identities identified by herself and Mrs. Li and gave up the efforts to claim more desirable identities as an English learner.

\section{Discussions and Conclusion}

Even though single case study is sometimes judged to be lacking in rigor, comparability, and replicability, it is an extremely valuable research method analyzing how people frame behaviors in a certain community (Barzelay, 1993). This study has significant theoretical and educational implications for our understanding of the identity construction and negotiation experienced by students and the ways to improve students' frequency of participating in oral tasks in the EFL classroom setting. In addition to confirming that students may experience continuous struggle between self-identity and identity perceived by others, this study has looked at EFL students' oral communication more dynamically by extending the scope to view students' class behaviors as struggle between identities posed by themselves and other members in the same classroom CoP.

This study builds on the literature that learners' identity is situated (Gee, 2001). By examining the focal student's negotiation of identities as an EFL learner within the English classroom CoP and her oral performances in English class, the data have great indications for the investigation on the significance of identity negotiation in students' English learning and class oral participation. Empirical evidence was offered to illustrate how the focal 
student constructed and negotiated her identity as English learner in the EFL classroom community and how her oral communication behaviors in the EFL classroom was influenced by the shifting identities in the Chinese university context. It explains the focal student's "ambivalent desire to learn and practice English and the observed contradiction between focal student's identity as a highly motivated English learner and her little investment in classroom oral participation (Norton, 2013)."

In this study, Yan desired to be a student highly regarded by the teacher and peers. In order to achieve the imagined identity, she invested in participating in class oral tasks and handed in diaries to communicate with Mrs. $\mathrm{Li}$ in the beginning of the university study. Yet, after gradually realizing that her desired identity in the classroom community conflicted with her learner identity perceived by her teacher Mrs. Li, Yan conformed to the undesirable identity as a student not valued by the teacher and with little legitimacy for participation. It in turn reinforced Mrs. Li's views on Yan. Yan's identity as an inactive student seems sustained. As a result, Yan believed that she was not valued in English classroom community and was deprived of legitimacy for participation. Her interest in class oral participation decreased, which not only to a great extent caused her inactive class oral behaviors, but also reduced her investment in English learning as a whole.

Yan's changes of class oral behaviors were noticed by Mrs. Li. However, Yan's shift of identities and the conflict between Yan's imagined identity and her perceived identity as a member of the English classroom CoP, which to a great extent led to her inactive class behaviors, seemed to be neglected. Yan's status in the English class positioned by Mrs. Li was undesirable. If that continued, there were good chances that Yan would become a so-called "product of exam-oriented education" - the kind of students who is good only at taking examinations, with low communicative competence. Thus, it is insightful for teachers to consider what identity is more valued by the students and try to make it concrete and salient.

Communication confidence has often been cited as one of the factors greatly and directly influencing students' willingness to communicate in English and oral communication behaviors (Fushino, 2010; Hashimoto, 2002; Liu, 2005; Peng \& Woodrow, 2010; Yashima, 2002). Yan's case illustrates that high confidence in English communication does not necessarily relate to great contributions in class oral activities. Even for a student confident in her English competence and active in class oral participation, such as Yan, when she identifies herself as a student not valued in class and lack of legitimacy for access to the resources and opportunities that this community offers, she tends to withdraw from participating in it. It seems justified to claim that students' self-identity in class seemed more influential in shaping their oral participation than was their self-perceived English language proficiency.

Yan's experience indicates the close relationship between students' self-perceived identities in class, frequencies of oral participation, and interest in English learning. The three factors are interrelated. A student's self-identification about his status in the English class community may influence his interest in English learning and oral participation, and the changed class oral participation may in turn impact how he identifies himself and his interest in English learning. A reduced or increased interest in English learning may impact oral participation. The relationship between the three factors underlines the significance of investigating ways to improve students' engagement in the class community. Active participation in oral activities not only improves students' oral communicative competence, it helps the self-identification of students as valued English learners and their interest in progressing English learning.

This is a pioneering study which investigates EFL learners' oral communication in classroom setting through a CoP perspective. It confirms Chen (2010)'s claim that CoP construct is a powerful analytic tool to examine students' performances in a particular context. This study also shows that some concepts under or frequently appearing in the CoP theory, such as legitimacy, imagined identity, investment and identity negotiation are useful in analyzing members' engagement in a certain community in the educational setting.

This study also has implications for teaching practices by shedding light on the role of teachers in shaping students' identities and increasing students' frequency of class oral participation in the educational setting. In order to improve English educational outcomes, especially students' active involvement in class oral communication, it is critical for teachers to understand what students expect to attain through English learning. In Chinese tertiary education, learners' imagined community and their identities in this community shadow their relationships with English $(\mathrm{Gu}, 2009)$ and influence their investment in English learning. This study shows that students' investment in English learning and class oral participation is a means of securing their access to imagined communities and achievement of imagined identities. Understanding students' imagined identities can help in understanding their ongoing classroom behaviors. Teachers' neglect of learners' imagined identities may cause students' reluctance to participate in learning activities. One responsibility of the teacher is to make the 
students' imagined community concrete, tangible and accessible (Kanno \& Norton, 2003). Getting to know the students on a personal level also gives the teachers insight into their interests and goals and this can be used to help design classes with a higher degree of perceived relevance and usefulness.

Teachers should reflect on how to increase legitimacy for students' participation in classroom activities and avoid practices which tend to impose undesirable identities on students. In this study, Yan's self-identity as proficient English learner and active classroom participant were downplayed by Mrs. Li in her teaching practices. Yan decreased her engagement in the activities in the English classroom community, where her imagined identity as an outstanding student could not be achieved. Outside English class, in the context where Yan's imagined identity was highlighted, Yan attained higher legitimacy for participation, which enable further advancement in participation and involvement.

Teachers should restrain from showing preference for certain students. Teachers' apparent preference for a small group of students can trigger other students' sense of disillusionment and the feeling of being deprived of legitimacy for participation in class activities. As discussed above, students' self-perceived identities in the EFL classroom CoP may exert great influence on their class oral participation. Self-identification as members of the classroom CoP deprived of the legitimacy for participating in learning opportunities and with low self-value might negatively influence students' participation in EFL classroom oral communication.

Teachers should help the students to make a smooth transition from secondary to tertiary education. As winners in the highly competitive National College Entrance Exams, universities students in China are described as "the God's favored". Many of these students used to be top students in high school and enjoyed the admiration of classmates and attention of teachers. After entering universities, they found most people around them were as excellent as they were. Their sense of pride and superiority declined dramatically, perhaps triggering feelings of disillusionment. Yan's experience is a good example.

In addition to catering to the students, teachers should try to make one using English in communication part of students' imagined identities. Increased realization of the significance of oral proficiency to their imagined communities will increase students' investment in English language learning as a whole. In addition to frequent communication with the students about in what ways English could be used in their future lives and to further their career goals, preparing the students for potential future opportunities can be achieved by providing them with knowledge of English-speaking communities and English-associated cultures. Also, teachers can share their experiences in English communities with the students, which helps to expand the students' horizon by exposing them to new ideas and possibilities of future communities which include using English in communication. By this means, the students could look at themselves and their situations with new eyes (Wenger, 1998, p. 272) by exploring possibilities and reinventing themselves (p. 273).

\section{Acknowledgements}

This study is funded by Chinese Scholarship Council and Scientific Research Foundation for the Returned Overseas Chinese Scholars, State Education Ministry.

\section{References}

Anderson, B. (1991). Imagined communities: Reflections on the origins and spread of nationalism (Rev. ed.). London: Verso.

Barzelay, M. (1993). The single case study as intellectually ambitious inquiry. Journal of Public Administration Research \& Theory, 3(3), 305-318.

Bourdieu, P. (1977). The economics of linguistic exchanges. Social Science Information, 16(6), 645-668. https://doi.org/10.1177/053901847701600601

Cao Y. Q., \& Philp, J. (2006). Interactional context and willingness to communicate: A comparison of behavior in whole class, group and dyadic interaction. System, 34(4), 480-493. https://doi.org/10.1016/j.system.2006.05.002

CET Committee. (2006). CET 4 Syllabus. Shanghai Foreign Language Education Press.

Chen, X. N. (2010). Identity Construction and Negotiation Within and Across School Communities: The Case of One English-as-a-New-Language (ENL) Student. Journal of Language, Identity \& Education, 9(3), 163-179. https://doi.org/10.1080/15348458.2010.486274

Cheng, X. T. (2000). Asian students' reticence revisited. System, 28(3), 435-446. https://doi.org/10.1016/S0346-251X(00)00015-4 
CMoE document. (2007). College English Curriculum Requirements. Shanghai: Shanghai Foreign Language Education Press.

Fushino, K. (2010). Causal relationships between communication confidence, beliefs about group work, and willingness to communicate in foreign language group work. TESOL Quarterly, 44(4), 700-724. https://doi.org/10.5054/tq.2010.235993

Gee, J. P. (2001). Identity as an analytic lens for research in education. In W.C. Secada (Ed.), Review of research in education (Vol. 25, pp. 99-125). Washington DC: American Education Research Association.

Gu, M. Y. (2009). College English learners' discursive motivation construction in China. System, 37(2), 300-312. https://doi.org/10.1016/j.system.2008.11.006

Hashimoto, Y. (2002). Motivation and willingness to communicate as predictors of reported L2 use: The Japanese ESL context. Second Language Studies, 20(2), 29-70.

Kang, S. (2005). Dynamic emergence of situational willingness to communicate in a second language. System, 33(2), 277-292. https://doi.org/10.1016/j.system.2004.10.004

Kanno, Y., \& Norton, B. (2003). Imagined communities and educational possibilities: Introduction. Journal of Language, Identity \& Education, 2(4), 241-249. https://doi.org/10.1207/S15327701JLIE0204_1

Kubota, R. (2011). Learning a foreign language as leisure and consumption: Enjoyment, desire, and the business of eikaiwa. International Journal of Bilingual Education and Bilingualism, 14(4), 473-488. https://doi.org/10.1080/13670050.2011.573069

Lave, J., \& Wenger, E. (1991). Situated learning: legitimate peripheral participation. New York: Cambridge University Press. https://doi.org/10.1017/CBO9780511815355

Leech, N. L., \& Onwuegbuzie, A. J. (2011). Beyond constant comparison qualitative Data Analysis: Using NVivo. School Psychology Quarterly, 26(1), 70-84. https://doi.org/10.1037/a0022711

Littlewood, W. (1999). Defining and developing autonomy in East Asian contexts. Applied Linguistics, 20(1), 71-94. https://doi.org/10.1093/applin/20.1.71

Liu, J. (2007). Learner autonomy and Chinese university students' English proficiency: A quantitative and qualitative study. Doctor of Education Thesis, Regent University.

Liu, J. (2012). English language education across Greater China. Journal of Multilingual and Multicultural Development, 33(4), 424-428. https://doi.org/10.1080/01434632.2012.661440

Liu, M. H. (2005). Reticence, anxiety and performance of Chinese university students in oral English lessons and tests. PhD Thesis, The Chinese University of Hong Kong.

Norton, B. (1995). Social identity, investment, and language learning. TESOL Quarterly, 29(1), 9-31. https://doi.org/10.2307/3587803

Norton, B. (2000). Identity and language learning: gender, ethnicity and educational change. Harlow: Longman.

Norton, B. (2001). Non-participation, imagined communities and the language classroom. In M. P. Breen (Ed.), Learner contributions to language learning: New directions in research (pp. 159-171). New York: Pearson Education.

Norton, B. (2013). Identity and language learning: Extending the conversation (2nd ed.). Bristol, United Kingdom: Multilingual Matters.

Pavlenko, A., \& Norton, B. (2007). Imagined communities, identity, and English language learning. In J. Cummins \& C. Davison (Eds.), International Handbook of English Language Teaching (pp. 669-680). Dordrecht, Netherlands: Springer. https://doi.org/10.1007/978-0-387-46301-8_43

Peng, J. E. (2007). Willingness to communicate in an L2 and integrative motivation among college students in an intensive English language program in China. University of Sydney Papers in TESOL, 2, 33-59.

Peng, J. E. (2012). Towards an ecological understanding of willingness to communicate in EFL classrooms in China. System, 40(2), 203-213. https://doi.org/10.1016/j.system.2012.02.002

Peng, J. E., \& Woodrow, L. (2010). Willingness to communicate in English: A model in the Chinese EFL classroom context. Language learning, 60(4), 834-876. https://doi.org/10.1111/j.1467-9922.2010.00576.x

Pomerantz, A. I. (2001). Beyond the good language learner: Ideology, identity, and investment in classroom foreign language learning. PhD Thesis, University of Pennsylvania. 
Powell, H., Mihalas, S., Onwuegbuzie, A. J., Suldo, S., \& Daley, C. E. (2008). Mixed methods research in school psychology: A mixed methods investigation of trends in the literature. Psychology in the Schools, 45(4), 291-309. https://doi.org/10.1002/pits.20296

QSR International Pty Ltd. (2008). NVivo qualitative data analysis software (Version 9).

Swann, W. B. (1987). Identity negotiation: Where two roads meet. Journal of Personality and Social Psychology, 53(6), 1038-1051. https://doi.org/10.1037/0022-3514.53.6.1038

Ting-Toomey, S. (1999). Communicating across cultures. New York: The Guilford Press.

Wen, W. P., \& Clément, R. (2003). A Chinese conceptualisation of willingness to communicate in ESL. Language, Culture and Curriculum, 16(1), 18-38. https://doi.org/10.1080/07908310308666654

Wenger, E. (1998). Communities of practice: learning, meaning and identity. Cambridge: Cambridge University Press.

Wenger, E., McDermott, R. A., \& Snyder, W. (2002) Cultivating communities of practice: A guide to managing knowledge. Boston: Harvard Business Press. https://doi.org/10.1017/CBO9780511803932

Wilensky, H. N. (2011). Re-examining communities of practice: Contradiction, power and reification in professional communities. PhD Thesis, University of California.

Yanow, D., \& Schwartz-Shea, P. (2006). Interpretation and method: Empirical research methods and the interpretive turn. Armonk, NY: Sharpe.

Yashima, T. (2002). Willingness to communicate in a second language: The Japanese EFL context. The Modern Language Journal, 86(1), 54-66. https://doi.org/10.1111/1540-4781.00136

\section{Copyrights}

Copyright for this article is retained by the author(s), with first publication rights granted to the journal.

This is an open-access article distributed under the terms and conditions of the Creative Commons Attribution license (http://creativecommons.org/licenses/by/4.0/). 